九州大学学術情報リポジトリ

Kyushu University Institutional Repository

\title{
Descriptions of Two New Species of the Genus Cacopsylla (Hemiptera : Psyllidae) in Japan
}

Inoue, Hiromitsu

Faculty of Agriculture, Kyushu University

https://doi.org/10.5109/2690

出版情報: ESAKIA. 44, pp.143-152，2004-03-31. Entomological Laboratory，Faculty of Agriculture, Kyushu University バージョン：

権利関係 : 


\title{
Descriptions of Two New Species of the Genus Cacopsylla (Hemiptera: Psyllidae) in Japan*
}

\author{
Hiromitsu INOUE \\ Entomological Laboratory, Faculty of Agriculture, Kyushu University, \\ Fukuoka, 812-8581 Japan
}

\begin{abstract}
Two new species of the genus Cacopsylla are described from Japan. One of them, Cacopsylla swidae sp. m. feeding on Swida controversa (Cornaceae), is described based on adults and 5th instars. Cacopsylla swidae became clear to be identical with the Japanese species that had been erroneously identified as a European species, Cacopsylla melanoneura. As a result, Cacopsylla melanoneura is excluded from the psyllid fauna of Japan. Another new species, Cacopsylla yukawai sp. m., which is distinguished from $C$. swidae and $C$. melanoneura in the shapes of genal cones and genitalia of both sexes, is described based on adults.
\end{abstract}

Key words: European species, misidentification, new species, Swida controversa, taxonomy.

\section{Introduction}

Cacopsylla (Thamnopsylla) melanoneura Förster, 1848 (=Psylla melanoneura), which feeds on Crataegus spp. (Rosaceae) in Europe and Mongolia (Klimaszewski, 1963; Ossiannilsson, 1992), has been known from the whole Europe, Siberia, Mongolia, N. China (Kuwayama \& Miyatake, 1971; Ossiannilsson, 1992), and also from Japan (Hokkaido, Honshu, Shikoku, and Kyushu) (Miyatake, 1963; Inoue \& Yamauchi, 2001). However, the distributional records of $C$. melanoneura from Japan were based only on adult specimens collected from various plant species other than the known host plants (Miyatake, 1963; Inoue \& Yamauchi, 2001), and the nymph and a genuine host plant of $C$. melanoneura have never been found in Japan.

In May 2002, adults and nymphs of a psyllid species of the genus Cacopsylla Ossiannilsson were collected from Swida controversa (Cornaceae) in Shizuoka Prefecture, central Honshu, Japan. Adult features of the $S$. controversa-feeding species appeared to be identical with those of the Japanese species that had been identified as $C$. melanoneura by 
Miyatake (1963) and Inoue \& Yamauchi (2001). In addition, adult and nymphal features indicate that the $S$. controversa-feeding species is a new species and distinguishable from the genuine $C$. melanoneura in Europe. In this paper, the adult and nymphal stages of the new Japanese Cacopsylla species feeding on S. controversa are described, together with some biological information, based on the sufficient number of specimens collected from various localities in Japan.

This paper also contains a description of another new Japanese Cacopsylla species, adult of which is distinguished from $C$. melanoneura and the $S$. controversa-feeding new species in the shapes of genal cones and genitalia of both sexes.

\section{Materials and Methods}

At least 400 specimens dealt with in this paper were collected from Hokkaido, Honshu, Shikoku, and Kyushu during the period from 1953 to 2002. The external morphology of adult was examined under a binocular microscope for dry specimens, and detailed structures such as male genitalia were observed under a phase-contrast microscope for slide-mounted specimens. Nymphs were preserved in $70 \%$ ethanol, mounted on slides, and observed under a phase-contrast microscope. All illustrations were drawn from the slide-mounted specimens. Measurements are expressed in millimeter. Adult and nymphal morphological terminology follows usage mostly in Ossiannilsson (1992) and White \& Hodkinson (1982), respectively.

All holotypes are preserved in the collection of the Entomological Laboratory, Kyushu University, Fukuoka (ELKU). Other specimens are preserved in Osaka Museum of Natural History, Osaka (OMNH), Hiwa Museum for Natural History, Hiwa, Hiroshima (HIWA), Kurashiki Museum of Natural History, Kurashiki, Okayama (KURA), and specimens otherwise noted are in my own collection that is presently in ELKU.

\section{Cacopsylla (Hepatopsylla) swidae sp. $\mathrm{n}$.}

[Japanese name: Mizuki-kurosuji-kijirami]

(Figs. 1-9)

Psylla melanoneura Förster: Miyatake, 1963: 354; Inoue \& Yamauchi, 2001: 56.

Adult.

Coloration. Head and thorax reddish brown in ground color, with blackish stripes and markings on vertex, praescutum, and mesoscutum. Genal cone pale yellowish brown. Antenna dark brownish to blackish. Forewing transparent, rather whitish, with an obscure dark brownish marking near apex of claval suture; vein dark brown. Abdomen including 
genitalia blackish.

Measurements (100\%/10 우): Overall length 2.88-3.06/3.11-3.34; width of head 0.72$0.79 / 0.76-0.83$; length of antenna 0.91-0.98/0.93-1.01; length of forewing 2.40-2.55/2.592.81 ; length of hind tibia $0.47-0.53 / 0.47-0.54$.

Head (Fig. 1) strongly leaned downward, distinctly wider than mesoscutum. Vertex about half as long as wide, with a pair of deep depressions near occiput. Genal cones strongly deflexed, about 0.7 times as long as vertex, contiguous to each other or slightly divergent, distinctly narrow in apical half, subacute at apex. Antenna 1.2-1.3 times as long as width of head; shorter setae on apex of 10th segment more than half length of longer seta (Fig. 2).

Thorax strongly convex. Praescutum rather long, more than 0.6 times as long as wide. Mesoscutum distinctly shorter than the half of its width, about as long as praescutum. Forewing (Fig. 3) oblong-oval, about 2.3 times as long as wide; membrane with dense spinules in all cells; spinule-free bands along veins narrow, becoming narrower apically; costal margin nearly straight; pterostigma long and narrow, longer than the half of Rs; Rs strongly sinuate, not upturned apically; $\mathrm{M}$ slightly arched, about twice as long as $\mathrm{M}_{3+4}$; $\mathrm{CuA} 1$ moderately arched; width of cell cul nearly twice as long as length. Hind wing about 0.8 times as long as forewing. Meracanthus well developed, gently tapered and strongly downward apically, subacute at apex; hind tibia with a small basal spine; apical saltatorial spines arranged $1+2+1+1$.

Male genitalia (Fig. 4) rather small. Proctiger slender, curved caudad apically. Paramere slender, slightly shorter than proctiger, strongly produced cephalad basally, more or less constricted medially, subacute apically; apical tooth small, acute and projected cephalad; inner surface (Fig. 5) with dense bristles basally. Aedeagus distinctly beyond the top of proctiger; apical segment about 0.9 times as long as paramere, round and not hooked apically; basal segment curved strongly, about 1.7 times as long as apical segment. Subgenital plate somewhat triangular in lateral aspect.

Female genitalia (Fig. 6) rather small. Proctiger distinctly longer than subgenital plate, slightly sinuate and with sparse setae varied in length dorsally, with minute robust setae densely on apical two-fifth, slightly upward apically, truncated slantwise at apex. Subgenital plate with sparse setae entirely, acute upward at apex.

Nymph (5th instar).

Coloration. General color pale yellowish white. Sclerites of body pale brown. Eye reddish brown. Apical half of 7 th antennal segment black.

Measurements ( 8 individuals). Length of body 1.54-2.16; length of antenna 0.68-0.73; length of forewing-pad $0.67-0.77$; maximum width of outer circumanal pore ring 0.15 0.16 .

Body (Fig. 7) oval in general shape. Setae on margin and dorsum of body capitate in 


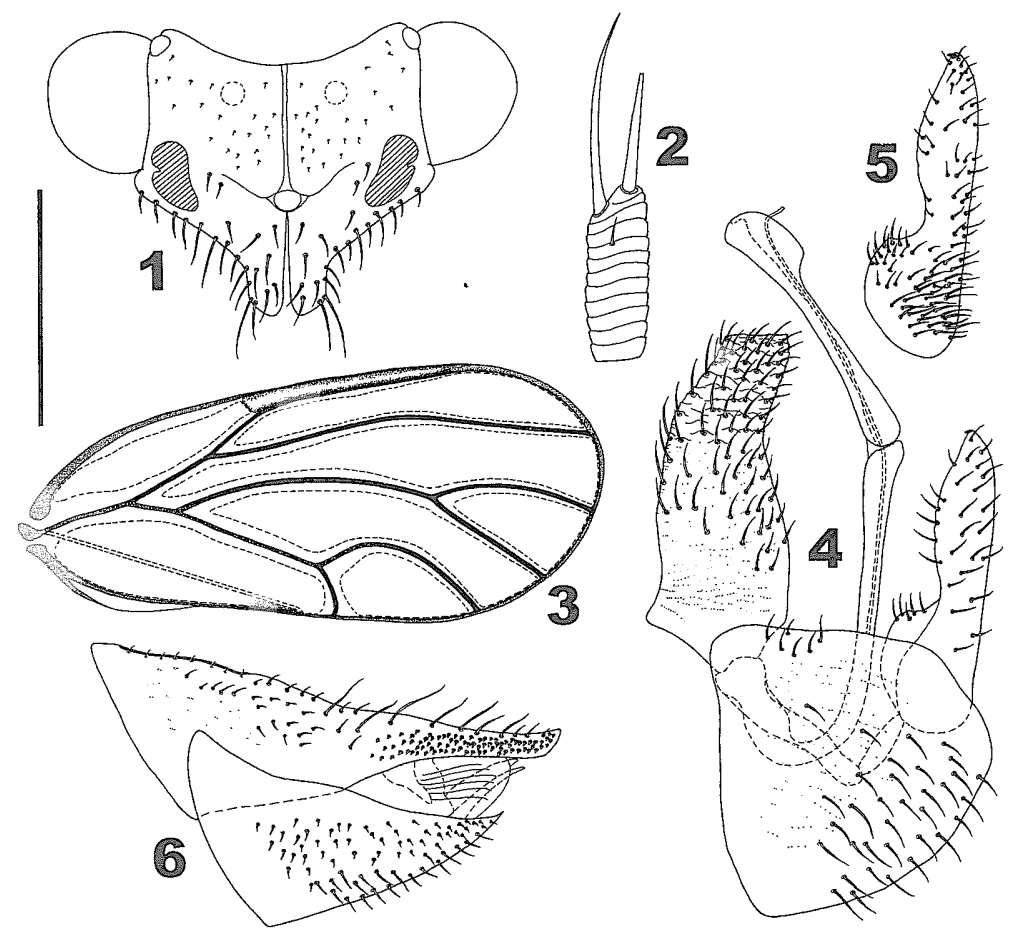

Figs. 1-6. Adult of Cacopsylla (Hepatopsylla) swidae sp. n.: 1, Head, frontal aspect; 2, 10th antennal segment; 3, right forewing; 4, male genitalia, lateral aspect; 5, right paramere, inner surface; 6 , female genitalia, lateral aspect. Scale line: $0.12 \mathrm{~mm}(2)$; $0.2 \mathrm{~mm}(4,5) ; 0.4 \mathrm{~mm}(1,6) ; 1.2 \mathrm{~mm}(3)$.

general.

Eye with a short capitate ocular seta. Antenna (Fig. 8) slender, as long as or slightly shorter than forewing-pad, consisting of seven segments, with a rhinarium on apices of 3rd and 5th segments, two on 7 th.

Thorax dorsally with short setae sparsely. Forewing-pad slightly more than twice as long as wide, with 10-12 long capitate setae on outer margin, with minute capitate setae rather densely on dorsum, with dense microsetae entirely on ventral surface. Hindwingpad with two long capitate setae apically, with minute capitate setae rather densely on dorsum, with dense microsetae along anterior margin on ventral surface. All legs stout; tibia with many capitate setae varied in length.

Abdomen round, somewhat tapered apically. Caudal plate with seven pairs of long capitate setae marginally, with sparse minute capitate setae and dense microsetae on 


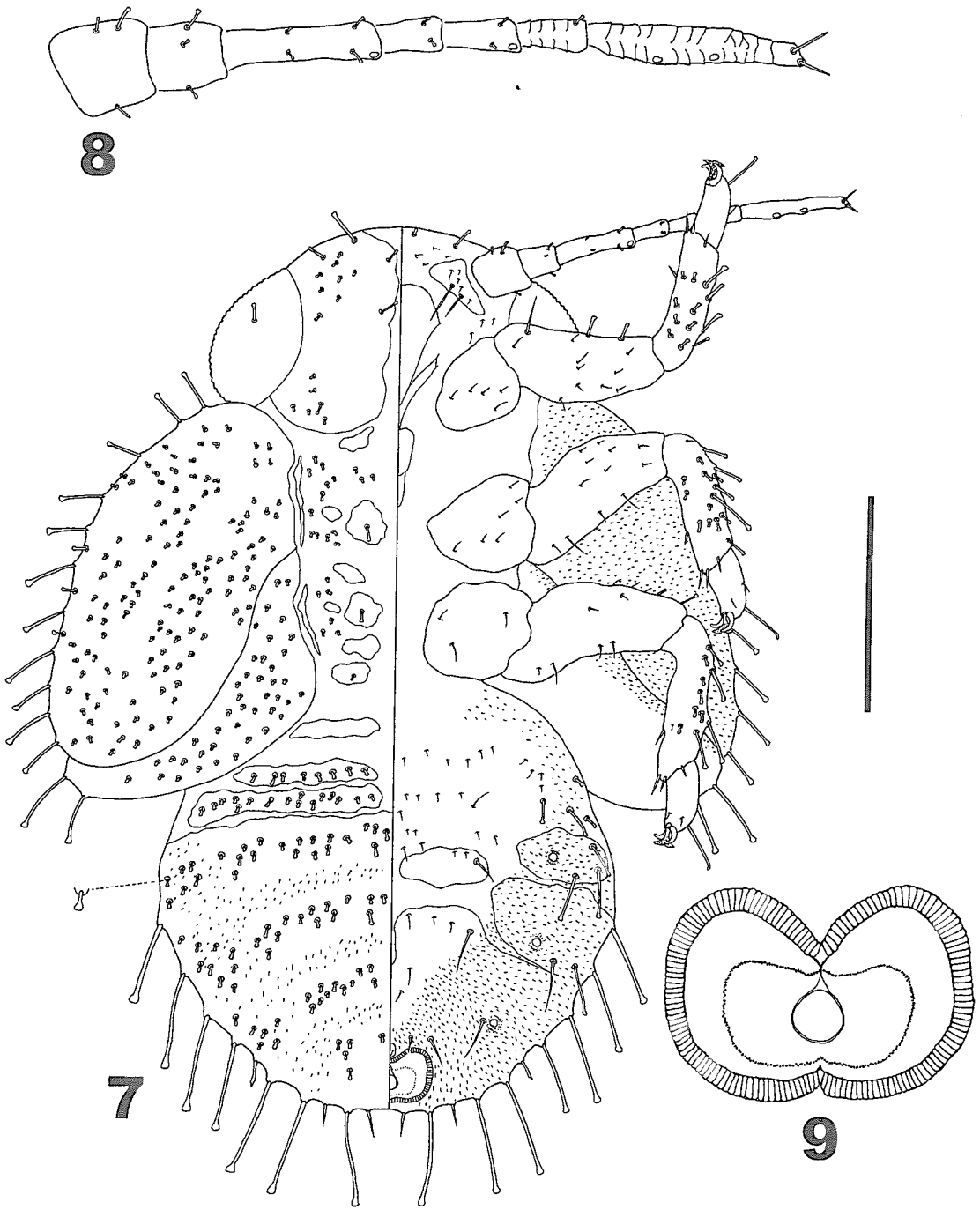

Figs. 7-9. Fifth instar of Cacopsylla (Hepatopsylla) swidae sp. n.: 7, Habitus, dorsal aspect (left) and ventral aspect (right); 8, antenna; 9, circumanal pore rings. Scale line: $0.1 \mathrm{~mm}$ (9); $0.2 \mathrm{~mm}(8) ; 0.4 \mathrm{~mm}$ (7). 
dorsum. Ventral sclerites with microsetae densely, with several simple and capitate long setae sparsely; anal plate fully fused with lateral and anterior sclerites. Anus located on ventral side apart from the apex of abdomen. Outer circumanal pore ring (Fig. 9) rather small, smooth heart-shaped, strongly curved in front, consisting of a single row of slit like pores; caudal margin of outer circumanal pore ring close to abdominal margin. Inner circumanal pore ring consisting of a single row of small pores.

Type series. Holotype $\sigma^{\top 7}$ (Type No. 3186, ELKU), Futo, Itô City, Shizuoka Pref., 12. v. 2002, on Swida controversa, J. Yukawa, K. Kiritani \& D. Yamaguchi leg. Paratopotypes $10 \sigma^{\top} 12$ 우 ( $2 \sigma^{\top} 2$ 우 on slides), same data as holotype (partly in OMNH). Paratypes [Hokkaido] 1 우, Aizankei, Kamikawa-gun, 17. vii. 1962, Y. Miyatake leg. (OMNH); $10^{\nearrow}$, same locality (700-900m), 4. vii. 2001, H. Inoue leg.; 1 우, Mt. Daisetsu, Kamikawa-gun, 22-24. vii. 1959, T. Kawarabata leg. (OMNH); $10^{\nearrow}$, Kurodake, Mts. Daisetsu, 21. vii. 1962, Y. Miyatake leg. (OMNH); $1 \sigma^{\nearrow}$, same locality, 23. vii. 1962, Y. Miyatake leg. (OMNH); 2 우, Nukabira, Tokachi, 19. vii. 1967, T. Saigusa leg. (OMNH); $10^{7} 3$ 우, Mt. Satsunai, 28. vii. 1967, A. Nakanishi leg. (OMNH); $10^{7} 1$ 우, same locality, 28. vii. 1967, H. Shima leg. (OMNH); 1 우, Shukushibetsu Rindô, Biratori, 1. vii. 1998, N. Takahashi leg.; 1 우, Nisshô-tôge (1,200m), Shimizu/Hidaka, 8. vii. 2001, H. Inoue leg.; 1

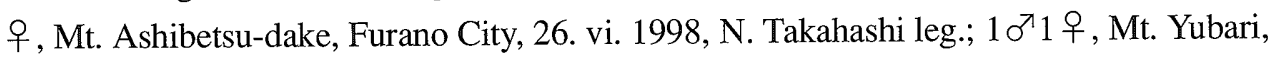
Yubari, Sorachi, 16. vii. 1967, T. Saigusa leg. (OMNH); $40^{\top} 3$ 우, same locality, 16. vii. 1967, A. Nakanishi leg. (OMNH); $1 \sigma^{7} 8$ 우, same locality, 16. vii. 1967, H. Shima leg. (OMNH); $1 \sigma^{7}$, Sapporo, 14. vii. 1953, K. Sasaki leg. (OMNH); $1 \sigma^{\nearrow}$, Jozankei, 16. vii. 1953, K. Sasaki leg. (OMNH). [Honshu] $2 \sigma^{\top} 4$ 우, Takada-Ohdake, Aomori Pref., 13. vii. 1967, T. Saigusa leg. (OMNH); $2 \sigma^{\top} 1$ 우, same locality, 14. vii. 1967, Y. Miyatake leg. (OMNH); $1 \sigma^{\top 1} 1$ 우, Hayachine, Iwate Pref., 2. viii. 1963, T. Saigusa leg. (OMNH); $90^{\top} 2$ 우, same locality (1,800-1,900m), 2. viii. 1963, T. Saigusa leg. (OMNH); $30^{\top} 4$ 우, Hachimantai, Akita Pref., 11. vii. 1962, Y. Miyatake leg. (OMNH); 1 우, same locality, 12. vii. 1962, Y. Miyatake leg. (OMNH); $1 \sigma^{\top}$, Mt. Mizugaki, Sutama, Yamanashi Pref., 13. vii. 2001, H Inoue leg.; $80^{7} 6$ 우 (1 $\sigma^{7}$ on slide), same locality, 13. vii. 2001, N. Takahashi leg.; $2 \sigma^{\top} 6$ 우, Kitazawa-tôge, Yamanashi Pref., 27. vii. 1959, Y. Miyatake leg. (OMNH); $87 \delta^{\top} 81$ 우 (3 $\sigma^{\top} 2$ 우 on slides), same locality, 11. vii. 2001, H. Inoue leg.; $230^{\top} 14$ 우, Kitazawa-tôgeSenjôgadake, 11. vii. 2001, N. Takahashi leg.; $20^{\top} 4$ 우, Mt. Senjôgadake-Mt. Shirane-Mt. Kitadake, Yamanashi Pref., 28-29. vii. 1959, Y. Miyatake leg. (OMNH); $1 \sigma^{\top}$, Mt. Kitadake, Yamanashi Pref., 12. vii. 2001, H. Inoue leg.; $2 \sigma^{\top} 1$ 우, Karuizawa, Nagano Pref., 7-14. vii. 1959, K. Morimoto leg. (OMNH); 11 우, Mt. Asama, Kitasaku-gun, Nagano Pref., 10. vii. 1966, Y. Miyatake leg. (OMNH); 1 우, Nagareyama City, Chiba Pref., 4. i. 2001, T. Tago leg. (OMNH); $4 \sigma^{\top} 4$ 우, same locality, 12. v. 2001, on S. controversa, T. Tago leg. (OMNH); $10^{7}$, Hachiôji City, Tokyo Met., 29. xii. 2001, T. Tago leg. (OMNH); $30^{7} 13$ 우 (1우 on slide), Nakatsuya (700m), Yoshiwa, Hiroshima Pref., 22. vii. 2000, at 


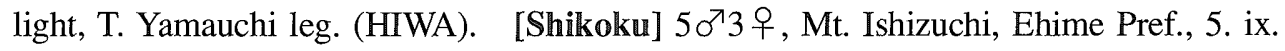
1953, K. Sasaki leg. (OMNH); 1 우, same locality (1,850m), 30. v. 1967, A. Nakanishi leg. (OMNH); 40 , same locality (1,900m), 30. v. 1967, H. Shima leg. (OMNH); $3 \sigma^{\top} 4$ 우, same locality, 17. vi. 1995, Y. Okushima leg. (KURA); $10^{\nwarrow} 1$ 우, Mt. Tsurugi, Tokushima Pref., 8. vi. 1964, T. Naito leg. (OMNH). [KKyushu] 1 우, Hikosan Biological Laboratory (670m), Mt. Hikosan, Soeda, Fukuoka Pref., 30. vii. 1998, at light, H. Inoue leg.; 2 우, same locality, 21 vii. 1999, at light, H. Inoue leg.; 1 우, Mt. Kujuh, Oita Pref., 18. vii. 1958, Y. Miyatake leg. (OMNH); $1 \sigma^{7}$ (on slide), Shiiya-tôge $(1,450 \mathrm{~m})$, Kumamoto Pref./Miyazaki Pref., 7. vi. 2001, H. Inoue leg.; 1 우, same locality, 25 vi. 1994, at light, S. Nomura leg.

Nymphal specimens examined (5th instar). [Honshu] 18 individuals (4 on slides), same data as holotype. [Kyushu] 8 individuals (4 on slides) Mt. Hikosan, Soeda, Fukuoka Pref., 5. vi. 2002, on S. controversa, H. Inoue leg.

Distribution. Japan (Hokkaido, Honshu, Shikoku, Kyushu).

Host plant. Swida controversa (Hemsl.) Soják (Cornaceae), 'Mizuki' in Japanese.

Remarks. Cacopsylla swidae is identical with the Japanese species that has been erroneously identified as a European species, C. melanoneura, in Miyatake (1963) and Inoue \& Yamauchi (2001). Cacopsylla swidae is distinguishable from $C$. melanoneura by having the following adult features: paramere strongly produced cephalad basally (not produced cephalad basally in $C$. melanoneura); aedeagus round and not hooked apically (subacute and slightly hooked apically in C. melanoneura); spinule-free bands of forewing narrower apically (broader apically in C. melanoneura, cf. Ossiannilsson, 1992). In nymphal features, $C$. swidae differs from $C$. melanoneura as follows: anal plate fused with lateral and anterior sclerites (fused only with lateral sclerites in C. melanoneura); abdomen without sectasetae (with 3 pairs of sectasetae in $C$. melanoneura). These nymphal features clearly indicate that both species belong to different subgenera, the former to Hepatopsylla Ossiannilsson, 1970 and the latter to Thamnopsylla Loginova, 1978 (cf. Ossiannilsson, 1992). As a result, C. melanoneura is excluded from the psyllid fauna of Japan.

Biology. The collecting records in January and December from Chiba Prefecture and Tokyo Metropolitan indicated that C. swidae overwintered as adults. In Shizuoka and Fukuoka Prefectures, nymphs of $C$. swidae were confirmed to be free-living and found on flower buds of $S$. controversa. New generation adults emerged from May to June, left the host plant soon after emergence, and moved to high altitudes. In summer, adults of $C$. swidae were found on various mountain plants such as Pinus pumila (Pallas) Regel, Abies mariesii Masters, Picea jezoensis (Sieb. et Zucc.) Carrière (Pinaceae), Betula ermanii Cham. (Betulaceae), and Sorbus commixta Hedl. (Rosaceae).

Etymology. The specific name is derived from the generic name of the host plant. 


\section{Cacopsylla yukawai sp. n.}

[Japanese name: Kabasuji-kijirami]

(Figs. 10-15)

\section{Adult.}

Coloration. General color chestnut brown. Genal cone, occiput, pronotum, parapteron, and caudal margin of praescutum cream yellow. Forewing translucent, whitish, rather brownish along veins; vein chestnut brown to dark brown. Abdomen including genitalia blackish.

Measurements ( $3 \sigma^{\top} / 5$ ㅇ $)$. Overall length 2.65-2.66/2.54-3.01; width of head 0.67/0.650.70 ; length of antenna $0.74-0.75 / 0.76-0.85$; length of forewing 2.20-2.26/2.14-2.52; length of hind tibia $0.46-0.48 / 0.44-0.54$.

Head (Fig. 10) strongly leaned downward, as wide as or slightly wider than mesoscutum. Vertex about half as long as wide, with a pair of rather shallow depressions near occiput. Genal cones about 0.8 times as long as vertex, slightly divergent, gently tapered apically, subacute at apex. Antenna 1.1-1.2 times as long as width of head; shorter seta on apex of 10th segment about half length of longer seta (Fig. 11).

Thorax weakly convex. Praescutum about 0.6 times as long as wide. Mesoscutum distinctly shorter than the half of its width, about as long as praescutum. Forewing (Fig. 12) oblong-oval, about 2.4 times as long as wide; membrane with conspicuously dense spinules entirely, without spinule-free band; costal margin gently arched; pterostigma long and narrow, distinctly longer than the half of Rs; Rs nearly straight; $M$ slightly arched, about 1.5 times as long as $\mathrm{M}_{3}+4$; $\mathrm{CuA}_{1}$ slightly arched; width of cell cul about 1.9 times as long as length. Hind wing slightly more than 0.8 times as long as forewing. Meracanthus somewhat large, gently tapered and slightly downward apically, subacute at apex; hind tibia without basal spine; apical saltatorial spines small, arranged $1+2+1+1$.

Male genitalia (Fig. 13) moderate in size. Proctiger slender, slightly curved caudad apically. Paramere stout, about 0.6 times as long as proctiger, slightly curved cephalad basally, curved caudad apically; inner apical tooth prominent, acute and projected cephalad; inner surface (Fig. 14) with retrorse setae sparsely. Aedeagus not beyond the top of proctiger; apical segment conspicuously stout, slightly longer than paramere, strongly extending apically; basal segment curved strongly, about 1.7 times as long as apical segment. Subgenital plate triangular in lateral aspect.

Female genitalia (Fig. 15) moderate in size. Proctiger distinctly longer than subgenital plate, slightly warped dorsally, blunt at apex, with sparse setae dorsally varied in length, with minute robust setae densely on apical third. Subgenital plate acute at apex, with sparse short setae entirely.

Nymph. Unknown. 


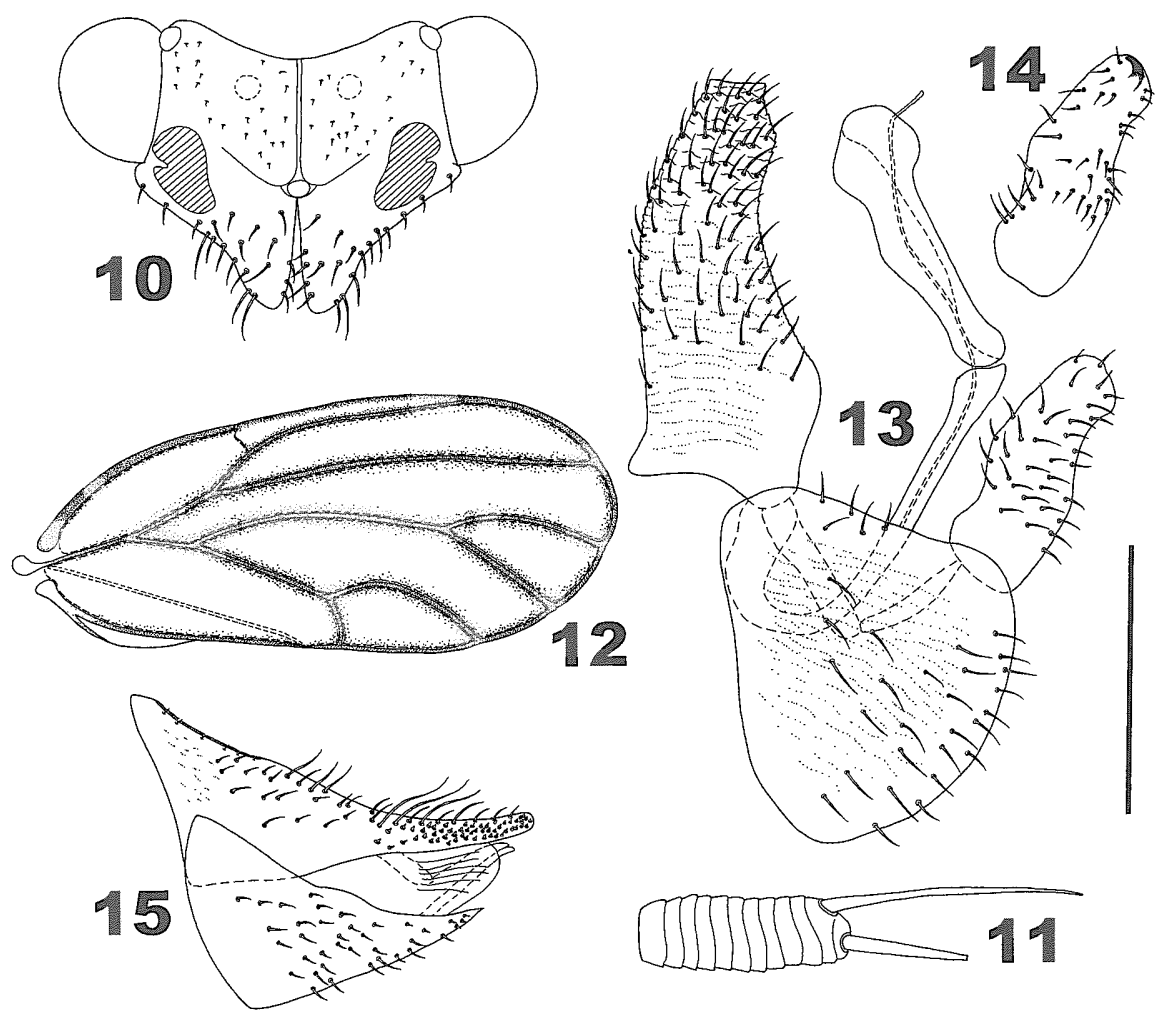

Figs. 10-15. Adult of Cacopsylla yukawai sp. n.: 10, Head, frontal aspect; 11, 10th antennal segment; 12, right forewing; 13, male genitalia, lateral aspect; 14, right paramere, inner surface; 15 , female genitalia, lateral aspect. Scale line: $0.12 \mathrm{~mm}(11)$; $0.2 \mathrm{~mm}(13,14) ; 0.4 \mathrm{~mm}(10,15) ; 1.2 \mathrm{~mm}(12)$.

Type series. Holotype $\sigma^{7}$ (Type No. 3187, ELKU), Kitazawa-tôge, Yamanashi Pref., Honshu, 11. vii. 2001, H. Inoue leg. Paratopotypes $3 \sigma^{\nearrow} 2$ 우 ( $1 \sigma^{\nearrow} 1$ 우 on slides), same data as holotype (partly in OMNH). Paratypes 1 우, Kitazawa-tôge-Senjôgadake, Yamanashi Pref., 11. vii. 2001, N. Takahashi leg.; $2 \sigma^{\top} 4$ 우 (1 $\sigma^{\top}$ on slide), Mt. Kitadake, Yamanashi Pref., 12. vii. 2001, H. Inoue leg.

Distribution. Japan (Honshu).

Host plant. Unknown.

Remarks. Cacopsylla yukawai is distinguished from C. swidae and C. melanoneura by the following adult features: forewing without spinule-free band, translucent in membrane, and chestnut brown in the coloration of vein (with spinule-free bands along veins, transparent in membrane, and dark brown in the coloration of vein in $C$. swidae and $C$. 
melanoneura); genal cone gently tapered to apex (distinctly narrow in apical half in $C$. swidae and $C$. melanoneura); apical segment of aedeagus conspicuously stout (slender in $C$. swidae and $C$. melanoneura); paramere stout (slender in $C$. swidae and $C$. melanoneura); female proctiger blunt at apex (truncated slantwise at apex in $C$. swidae and $C$. melanoneura).

The subgeneric status of $C$. yukawai, cannot be settled at the moment because its nymphal stage is unknown.

Etymology. The specific name, yukawai, honors Prof. Junichi Yukawa of ELKU in commemoration of his retirement.

\section{Acknowledgements}

I wish to express my gratitude to Prof. J. Yukawa (ELKU) for his constant guidance and critical reading of the early draft. I also express my thanks to Mr. Y. Miyatake (Kansai University) for critical reading of the early draft and for the loan of specimens deposited in OMNH. My thanks go also to Assoc. Prof. O. Tadauchi and Dr. S. Kamitani (ELKU) for their constant encouragement, and to Dr. Y. Okushima (KURA) for the loan of specimens deposited in KURA, and to Dr. N. Takahashi (Institute of Biological Control, Kyushu University) and Mr. T. Yamauchi (Hiroshima University) for the gift of materials.

\section{References}

Inoue, H. \& T. Yamauchi, 2001. Jumping plant-lice (Hemiptera: Psylloidea) of Hiroshima Prefecture. Misc. Rep. Hiwa Mus. Nat. Hist., 40: 53-58. (In Japanese.)

Klimaszewski, S. M., 1963. Blattflöhe (Homoptera, Psyllidae) aus der Mongolei. Ann. Zool., Warszawa, 21: 61-79.

Kuwayama, S. \& Y. Miyatake, 1971. Psyllidae from Shansi, North China (Hemiptera). Mushi, 45: 51-58.

Miyatake, Y., 1963. A revision of the subfamily Psyllinae from Japan. I (Hemiptera: Psyllidae). J. Fac. Agr., Kyushu Univ., 12: 323-357.

Ossiannilsson, F., 1992. The Psylloidea (Homoptera) of Fennoscandia and Denmark. Fauna Ent. Scand., 26: 1-346.

White, I. M. \& I. D. Hodkinson, 1982. Psylloidea (nymphal stages) (Hemiptera, Homoptera). Handbooks for the Identification of British Insects, Vol. II, Part 5(b): 150. 